\title{
TOWARDS AN INTERNATIONAL HUMAN RIGHTS JUDICIARY?
}

\author{
Professor dr. juris Geir Ulfstein ${ }^{1}$
}

\section{INTRODUCTION}

The sharp increase in international courts and tribunals in recent decades, such as the International Tribunal for the Law of the Sea (ITLOS), the WTO dispute settlement system, and the International Criminal Court, means that the international order is, progressively, subject to the rule of law.

Human rights are in the forefront in this development. We have regional human rights courts in Europe, in the Inter-American system and in Africa - but not yet in Asia. At the global level there are a number of global treaty bodies, such as the Human Rights Committee and the Committee Against Torture. These committees examine state reports, but many can also receive individual complaints. Hence, they have a judicial function. Human rights are also addressed by non-human rights international courts, such as the International Court of Justice.

But now the European Court of Human Rights (ECtHR), other regional courts and the global human rights system face criticism from different parts of the world - not only from traditional skeptics, but increasingly also from devoted supporters. The discontent relates to these institutions' inefficiency and ineffectiveness in delivering justice, as well as their intervention in long-standing political, legal, cultural and religious traditions in member states. This has resulted in reform processes both at the global and regional level.

In the following, I will first discuss the functions of the ECtHR, then the global human rights treaty bodies and courts, and finally the role of national courts. The purpose is to examine to what extent the national, regional and global level act together as a comprehensive judiciary - even as a constitutionalized judicial architecture.

\section{THE EUROPEAN COURT OF HUMAN RIGHTS}

The European Court of Human Rights (ECtHR) is without doubt one of the most successful international human rights treaty bodies. With a case law which outnumbers that of any other regional and international human rights instrument, the Court accounts for changes in national law and living conditions in a Europe of 47 member states and over 850 million inhabitants.

But the success of the Court threatens its survival. As of 31 October 2013 the Court had 107, 600 pending cases. ${ }^{2}$ Ca $95 \%$ of these cases is inadmissible; still the number of cases is staggering. Many of the cases are repetitive, meaning that the real problem is that member states do not implement the Court's judgments properly. Four states (Russia, Italy, Ukraine, Turkey and Serbia) accounted for 2/3 $(66,2 \%)$ of the pending cases. ${ }^{3}$

The Court is not only exposed to overload and difficulties in national implementation of its judgments. It is also faced with increasing skepticism. This is amply illustrated in both the case on crucifixes in Italian classrooms ${ }^{4}$ and the cases on prisoners' voting rights against the $\mathrm{UK}^{5}$. Ten states intervened as

\footnotetext{
${ }^{1}$ Department of Public and International Law, University of Oslo. This article was written under the auspices of ERC Advanced Grant 269841 MultiRights - on the Legitimacy of Multi-Level Human Rights Judiciary; and partly supported by the Research Council of Norway through its Centres of Excellence Funding Scheme, project number 223274 PluriCourts - The Legitimacy of the International Judiciary.

2 See: http://www.echr.coe.int/Documents/Stats_pending_month_2013_BIL.pdf.

${ }^{3}$ See overview of the 2012 statistics: http://www.echr.coe.int/Documents/Stats analysis 2012_ENG.pdf.

${ }^{4}$ Lautsi and Others v. Italy (Application no. 20814/06) [GC], Judgment 18 March 2011.
} 
'third parties' in the crucifix proceedings before the Court's Grand Chamber. In the UK there is heated debate on the country's relationship to the European Convention on Human Rights (ECHR).

There has been an ongoing European reform process, resulting in the Interlaken, Izmir and Brighton Declarations of 2010, 2011 and 2012. ${ }^{6}$ The Declarations have given strong support to the Court, while highlighting the principle of subsidiarity, as well as the margin of appreciation doctrine as main elements of the Court's jurisprudence. This acknowledges national authorities' primary function in implementing the ECHR. Pursuant to the Brighton Declaration, two new Protocols, No. 15 on inclusion of the principle of subsidiarity and the margin of appreciation in the ECHR preamble and No. 16 on requests for advisory opinions from national courts, have been adopted. The reforms have also included procedural amendments.

The reflections on the Court's long term future should, however, take a wider scope and address what kind of court is desirable in the coming decades. One of the issues is whether the Court should act more like an international constitutional court. But the ECtHR is an international court with its legal basis in international law. How could such an international court perform constitutional functions?

The ECtHR acts already as a constitutional human rights court for Europe, in the sense that it reviews decisions by the highest national courts. But the fact that it is an international court is reflected in the formal basis for its review, which is a treaty, rather than a constitution. The human rights provisions in the ECHR and national constitutions are generally based on the same values. But the ECHR must be interpreted in accordance with the canons of treaty interpretation, as opposed to a national constitution. If the ECtHR goes beyond its legal competence, the member states may invoke doctrines like ultra vires, which is hardly applicable in a national constitutional context.

Furthermore, the review by the ECtHR is subject to the principle of subsidiarity. This principle has not been expressly stated in the ECHR, and will only become part of the Convention when Protocol 15 enters into force. But the principle has been acknowledged by the Court in the form of the margin of appreciation. Subsidiarity is also an aspect of the ECtHR being an international court, in the sense that the Court acknowledges the need for national solutions to the international obligations, as long as they do not threaten the effective protection of human rights. This distinguishes the ECtHR from a national constitutional court, since a national court will not need to take national autonomy into consideration. On the other hand, the application of the principle of subsidiarity by the Court may be seen as a constitutional approach to human rights review since, in reviewing acts by national constitutional organs, the ECtHR takes due account of the respective functions of these organs and of the Court itself.

Allowing the Court to select its cases would be adding another feature comparable to those of national constitutional - or supreme - courts. If the ECtHR should be given the competence to select its cases, the Court should deal with cases suitable to providing guidance for its own future practice as well as that of national courts. But the function of the ECtHR as an international court should be reflected in its selection of the most important cases in terms of their gravity as violation of human rights. In these cases, the Court would provide individual justice, i.e. ensuring effective remedies for each of the applicants, rather than rendering constitutional justice in establishing general precedents. The ECtHR should also deal with repetitive cases and cases reflecting systemic failures in the national legal order, possibly in the currently used pilot judgments. ${ }^{7}$ While also constitutional courts may go beyond finding a violation of the national legal order in the instant case, dealing with systemic failures at the national level may be considered special for the ECtHR as an international court.

\footnotetext{
${ }^{5}$ Hirst v. the United Kingdom (no. 2) (Applicationo. 74025/01) [GC], Judgment 6 October 2005.

${ }^{6}$ See: http://www.echr.coe.int/Pages/home.aspx?p=court/reform\&c=.

${ }^{7}$ P Leach, "No Longer Offering Fine Mantras to a Parched Child? The European Court's Developing Approach to Remedies " in A Føllesdal, B Peters and G Ulfstein (eds), Constituting Europe: the European Court of Human Rights in a national, European and global context (Cambridge University Press, 2013), 142-181.
} 
Finally, the role of the ECtHR differs from national constitutional courts since it, being part of a different legal system, i.e. international law, cannot coerce national constitutional organs to comply with its judgments. The Court can generally rely on faithful implementation of its judgments by national courts. But if national authorities find that the Court goes too far in imposing its interpretations despite long-standing national traditions, the result may be lack of national political support and funding, reluctance to implement the judgments, and eventually that one or more states may decide to withdraw from the ECHR. The Court may therefore need to calibrate its interference in national autonomy with what is generally acceptable to member states. But it is also dependent on persuading national authorities, including national courts, about the legal appropriateness of its interpretation. This may - as I will come back to - facilitate a dialogue between the ECtHR and national courts, and thus a form of constitutional interaction between the international and the national level.

\section{THE GLOBAL HUMAN RIGHTS JUDICIARY}

The treaty bodies established by the UN human rights conventions shall oversee national implementation of the international obligations. They have been a success in the sense that they have increasingly extended their functions and importance in the examination of state reports, dealing with individual complaints, and adoption of general comments on interpretation of the treaty obligations both through their political sensitivities and their creative use of legal techniques, such as the doctrine of 'implied powers'.

But the treaty bodies are also facing challenges. They have been criticized for an excessively expansive interpretation of the substantive obligations; that the increase in human rights conventions with their supervisory treaty bodies go too far in legalization and judicialization; and that the system is overloaded, resulting in increasing backlogs. This has resulted in the current treaty body strengthening process by the UN High Commissioner for Human Rights and the UN General Assembly. ${ }^{9}$

Authors have pointed to examples where the treaty bodies allegedly may have gone too far in their interpretation. Kerstin Mechlem refers to General Comments adopted by the Committee on Economic, Social and Cultural Rights (CESCR) on the obligations of international organisations, states' extraterritorial obligations and the concept of 'core obligations'. Urfan Khaliq and Robin Churchill speak of the CESCR's 'quasi-legislative approach to certain issues, notably the rights to adequate housing and water' and that the Human Rights Committee (HRC) with regard to the right to life has adopted 'an extremely expansive approach, one that encompasses, inter alia, housing, health and nutrition'. ${ }^{10}$

It is difficult to see that the treaty bodies generally apply interpretation methods deviating from the methods used in other parts of international law. The expansion of treaty obligations through an effective or dynamic interpretation is at the outset perfectly legal and well-advised. But it is a doubleedged sword to the extent that states may argue that the treaty bodies do not respect traditional canons of treaty interpretation, and thus engage in law-making beyond their mandates as supervisory bodies. Such opinions may prevent implementation of treaty bodies' findings in national law. But they may also prevent the necessary political and financial support by states in the current treaty body strengthening process. It is therefore of importance that the treaty bodies balance the need for effective

\footnotetext{
${ }^{8}$ H Keller and G Ulfstein, "Conclusions" in H Keller and G Ulfstein (eds), UN Human Rights Treaty Bodies. Law and Legitimacy (Cambridge University Press, 2012) 414-426, 416.

${ }^{9}$ See: http://www.ohchr.org/EN/HRBodies/HRTD/Pages/TBStrengthening.aspx.

${ }^{10} \mathrm{~K}$ Mechlem, 'Treaty Bodies and the Interpretation of Human Rights'Vanderbilt Journal of Transnational Law 422009 905-947, 931and U Khaliq and R Churchill, "The protection of economic and social rights: a particular challenge?" in H Keller and G Ulfstein (eds), UN Human Rights Treaty Bodies. Law and Legitimacy (Cambridge University Press, 2012) 199-260, 260.
} 
human rights protection through their interpretation, while respecting accepted methods of treaty interpretation - and keeping an eye on what states generally may be willing to implement.

The treaty bodies - unlike the ECtHR - do not seem to accept a margin of appreciation in states' implementation of their treaty obligations. ${ }^{11}$ The wide diversity in cultural, religious and political conditions between states at the global level may be an argument both pro and contra the application of a margin of appreciation. On the one hand, respect for the diversity may result in diluted obligations. But, on the other hand, it is difficult to understand why such a margin should only be accepted at the European level, where the diversity is lesser. It may be argued that a margin of appreciation at the global level is both legally justified - and good policy if the treaty bodies' findings shall be domestically implemented and the supervisory system shall enjoy continued support, rather than fostering antagonism. But the treaty bodies should not try to establish a global common denominator of what all states might accept, at the expense of effective human rights obligations. The challenge of balancing national autonomy and effective human rights protection at the global level is thus a delicate task for the treaty bodies.

The increased activity and the rise in the number of treaty bodies have also created problems in terms of over-reaching their capacity to deal with state reports and individual complaints, resulting in increasing backlogs. ${ }^{12}$ So far, the treaty bodies have not received the excessive number of individual applications as the ECtHR. But taking into consideration their global scope, the potential for drowning in future cases should be taken seriously.

When it comes to dealing with individual complaints, the treaty bodies are better suited to develop principles for interpretation of the treaty obligations than acting as supervisory organs. They have neither possibility for effective fact-finding nor do they allow oral proceedings by the parties, and their non-binding findings have generally less importance in national law than international judgments. This, combined with the current and potentially dramatically expanding overload, are factors in favour of a competence for the treaty bodies to select their cases based on their suitability to create useful precedents, rather than primarily rendering individual justice. In this respect, the treaty bodies should like suggested above for the ECtHR - acquire more of a constitutional court function. But, like the ECtHR, the treaty bodies should also deal with serious violations of human rights and systemic failures in the national system - or unwillingness to implement treaty bodies' findings.

Unlike the ECtHR, the treaty bodies cannot adopt binding judgments. The legal status of their findings has been the subject of debate. The HRC stated in its General Comment No. 33 (2008) that the Committee's function is not 'as such, that of a judicial body'. But the reasoning and conclusion of this Comment give an impression of the Views as tantamount to being legally binding.

The International Court of Justice (ICJ) expressed its opinion about the legal status of the HRC's findings in the Diallo case (2010). The Court held that it was 'in no way obliged, in the exercise of its judicial functions, to model its own interpretation of the Covenant on that of the Committee'.

Furthermore, the ICJ only applied the HRC's practice as support for its own interpretation: '[t]he interpretation above is fully corroborated by the jurisprudence of the Human Rights Committee'. But the Court stated that the HRC's practice should be given 'great weight' since the HRC 'was established specifically to supervise the application of that treaty'. The ICJ also referred to the need for promoting 'the necessary clarity', the 'essential consistency' and 'legal security' for both individuals and states. ${ }^{13}$ Thus, although not legally binding, states have an obligation to take the treaty bodies' findings seriously by ascribing them 'great weight'.

\footnotetext{
${ }^{11}$ B Schlütter, "Aspects of human rights interpretation by the UN treaty bodies", ibid 261-320, 304.

${ }^{12}$ Unite Nations High Commissioner for Human Rights, Strengthening the United Nations Human Rights Treaty Body System (2012), 23.

${ }^{13}$ Ahmadou Sadio Diallo (Republic of Guinea v. Democratic Republic of Congo), Merits, Judgment [2010] ICJ Rep 639, para. 66.
} 
The treaty bodies must not only overcome the duality between international and national legal obligations, but also the non-binding character of their findings. It would seem that the ICJ not only struck the right balance between acknowledging the non-binding legal status of the findings and the need for taking the findings into account. The obligation to attach 'great weight' to the findings has also the benefit of engaging national courts in a dialogue with the treaty bodies, in the sense that they must give reasons for not applying the interpretation authorized by the treaty bodies. ${ }^{14}$

But there are also formal courts at the global level dealing with human rights. While general in its scope, the ICJ is increasingly used in human rights issues, such as the Wall case (2004) ${ }^{15}$, the Genocide case (2007) ${ }^{16}$ and the Diallo case (2010 and 2012). ${ }^{17}$ The increased involvement of the ICJ in human rights is at the outset good for the protection of such rights since it can supplement regional and global human rights protection. The ICJ has of course the advantage compared to the treaty bodies that its judgments are legally binding.

But the ICJ acting as a human rights court raises also challenges. First, the Court must relate to the jurisprudence of other international courts and tribunals, particularly the specialized global and regional judicial bodies in this field. This has so far not created problems. On the contrary, as exemplified by the Diallo case, the ICJ has been supportive of the findings by human rights treaty bodies. In spite of formal fragmentation between the judicial bodies, the substantive findings are consistent. Hence, it may be argued that the international judiciary is working in a constitutionalized manner.

A second question is the role of the relevant individual in cases before the ICJ. The individual has no formal control over whether a case is raised before the Court, or over the proceedings (including evidence and claims), or whether s/he would obtain any compensation imposed by the Court. This raises the issue of whether the individuals concerned should be accorded any procedural rights in such inter-state disputes.

Human rights issues may also appear before other international judicial organs, such as the WTO dispute settlement system. While there a potential for divergent interpretation of the human rights obligations exists, especially in confrontation with other international legal regimes, it does not, so far, seem that such conflicts have led to major difficulties. ${ }^{18}$

Neither the ICJ nor other specialized courts - due to their inter-state character - can replace the regional human rights courts and the global treaty bodies, which in their accessibility for individuals have a transnational character. It seems so far that the different courts and treaty bodies play complimentary rather than competing roles.

A World Court of Human Rights has been proposed by Manfred Nowak and Martin Scheinin. ${ }^{19}$ The Court would be established by a separate treaty, and thus not require amendment of any existing

\footnotetext{
${ }^{14}$ G Ulfstein, "Individual Complaints" in H Keller and G Ulfstein (eds), UN Human Rights Treaty Bodies. Law and Legitimacy (Cambridge University Press, 2012) 73-116, 100.

${ }^{15}$ Legal Consequences of the Construction of a Wall in the Occupied Palestinian Territory, Advisory Opinion [2004] ICJ Rep 136.

${ }^{16}$ Application of the Convention on the Prevention and Punishment of the Crime of Genocide (Bosnia and Herzegovina v. Serbia and Montenegro), Judgment [2007] ICJ Rep 43.

${ }^{17}$ Ahmadou Sadio Diallo (Republic of Guinea v. Democratic Republic of Congo), op. cit. and Ahmadou Sadio Diallo (Republic of Guinea v. Democratic Republic of the Congo, Judgment, 19 June 2012.

${ }^{18}$ See E De Wet and J Vidmar, Hierarchy in International Law: the Place of Human Rights (Oxford University Press, 2012) and S Joseph, Blame it on the WTO?: a Human Rights Critique (Oxford University Press, 2011).

${ }^{19}$ M. Nowak, 'The Need for a World Court of Human Rights', 7 Human Rights Law Review

(2007) pp. 251-259 and M. Scheinin, 'The Proposed Optional Protocol to the Covenant on Economic, Social and
} 
human rights conventions. Each state could be given the opportunity to choose the conventions to which the Court would be authorized to have judicial functions, and they could even choose conventions that currently do not have any complaints procedure. They could then opt-out from the complaints procedure of the same conventions. Nowak suggests that the Court could be empowered to judge also in relation to the legality of acts by non-state actors, such as inter-governmental organizations (e.g. the UN, EU, the World Bank, the WTO and NATO) and multinational companies; it could impose reparations in cases of violations; and it could adopt binding interim measures. Scheinin submits that the Court could be either a first instance or an appeals court for decisions taken by the treaty bodies.

This proposal has recently been strongly criticized by Philip Alston. He argues that 'the proposal is fundamentally misconceived. In addition to practical issues such as political feasibility and cost, the proposal overstates the role that can and should be played by judicial mechanisms, downplays the immense groundwork that needs to be undertaken before such a mechanism could be helpful, sets up a straw man to be attacked by those who thrive on exaggerating the threat posed by giving greater prominence to human rights instruments at the international level, and distracts attention from far more pressing and important issues. ${ }^{20}$

Such a court would combine the transnational character of the human rights treaty bodies in allowing standing for individuals while being delegated authority to rendering binding judgments. The discussion about a World Court of Human Rights raises the issue of whether there are limits to the international judicialization, or even constitutionalization of the international human rights judiciary.

Should a few persons be given powers to determine with binding effect the relationship between a government and its citizens, or would this be too much delegation of power? Or does it depend on the modalities in designing the court and its functions? For example, is there a trade-off between subsidiarity in form (non-binding decisions) and substance (margin of appreciation), in the sense that binding judgments by a World Court would need to apply such a wide margin of appreciation that we are better served with the existing non-binding findings of the human rights treaty bodies? Is there a need to strike a balance between the benefits of binding regional judgments at the potential expense of universally consistent practice? Of no less importance is the realism of such as World Court, i.e. its feasibility.

\section{THE ROLE OF NATONAL COURTS}

What should be the role of national courts? These courts are established as part of the national legal order, not of international law. Hence, their relationship with the ECtHR and the global human rights treaty bodies is a matter of national legislation and practice developed by the national judiciary.

The principle of consistent interpretation is generally acknowledged in national legal orders, implying that national law shall, as a point of departure, be interpreted in accordance with the state's international obligations. This means that national courts should choose interpretations that serve to implement judgments by the ECtHR and other international courts against the state, and that they, according to the ICJ, should attach 'great weight' to the findings by the global treaty bodies. They should also pay due respect to precedents and the general practice of international courts and tribunals.

Cultural Rights: A Blueprint for UN Human Rights Treaty Body Reform without Amending the Existing Treaties', 6 Human Rights Law Review (2006) pp. 131-142. See also the most recent version: J Kozma, M Nowak and M Scheinin, A World Court of Human Rights - Consolidated Statute and Commentary (Studienreihe des Ludwig Boltzmann Instituts fOr Menschenrechte herausgegeben von Manfred Nowak, Fiona Steinert und Hannes Tretter, 2010).

${ }^{20}$ Alston, Philip, Against a World Court for Human Rights (October 23, 2013). Ethics and International Affairs, 2014, Forthcoming; NYU School of Law, Public Law Research Paper No. 13-71. Available at SSRN:

http://ssrn.com/abstract=2344333. 
But national courts have certain discretion both when it comes to interpretation of judgments by the ECtHR and other international courts to which the state has been a party, as well as choosing the appropriate means to implement the judgment. The flexibility is wider in implementing the nonbinding findings of the global treaty bodies. The effects of international precedents and practice beyond the binding effect on the parties to the case are also a matter of interpretation - and a possibility of interaction.

Consequently, national courts may potentially play a role in influencing the interpretation in future cases before the ECtHR and other international courts and treaty bodies. National courts may point to the significance of local conditions, or through well-reasoned judgments, try to persuade the international judicial organs to choose a different interpretation. These forms of interaction represent an application of the principle of subsidiarity, but now by national courts. A more general practice by national courts may also amount to subsequent state practice - or in the case of the ECtHR: a European practice - that the international judicial organs must take into account. In this sense, the system can be said to function in a constitutionalized way, by defined roles of the international and national judiciary, acting together.

On the other hand, national courts may refer to the principle of dualism between international and national law, and, on a principled basis, refuse to implement an international judgment in the national legal system. In such case, the special features of the relationship between the international and national legal system are displayed. This may be seen as an aspect of pluralism between different legal systems, rather than a transnational constitutional legal order. ${ }^{21}$

But such a principled stance of national authorities not to implement an international judgment may have a snow-balling effect and encourage other states to reject international judgments - and thus undermine efforts to protect human rights and build more respect for the international rule of law. What is more, respect for judgments by the ECtHR and findings of human rights treaty bodies are essential also for states with a long human rights tradition. These states and their population have benefitted from decisions by the international judiciary, although they may have been strongly resisted at the point of adoption. Thus, states should generally comply with judgments from the European Courts while paying due respect for the findings of the human rights treaty bodies - both to support the international rule of law and to the benefit of their own population.

This means that national courts should go beyond a consistent interpretation and apply an internationalized constitutional interpretation in the relationship between the national and the international judiciary. Hence, national courts should not only respect the findings of international courts and tribunals, but interact in a constructive way in the interpretation of the international obligations. On the other hand, the international judicial organs should take account of the legitimate roles of national constitutional organs, including national courts.

The national and the international judiciary belong to different legal orders, and none of them can coerce the other to respect their decisions. They must therefore work together in order to ensure effective protection of human rights, while ensuring due respect for national democratic and judicial autonomy. In one sense this represents a transnational judiciary with constitutional characteristics. The particular features of this judiciary must, however, be determined of the basis of the interaction between two legal systems - international and national law.

\footnotetext{
${ }^{21}$ See N Krisch, Beyond Constitutionalism. The Pluralist Structure of Postnational Law (Oxford University Press, 2010) and S Greer and L Wildhaber, 'Revisiting the Debate About 'constitutionalising' the European Court of Human Rights', Human Rights Law Review 1242012 655-687.
} 